Article received on $31^{\text {st }}$ March 2015

Article accepted on $12^{\text {th }}$ May 2015

UDC: $316.323 .63: 78.01$

\title{
Andrija Filipović*
}

Singidunum University, Belgrade

Faculty of Media and Communications

\section{ZONES OF NON-COMMUNICATION: MUSIC AND THE RELATIVE IMMANENCE OF CAPITALISM}

\begin{abstract}
The goal of this paper is to show not what music is, but what music as a sort of political practice can do in the age of contemporaneity. The age of contemporaneity is defined by the relative immanence of capitalism, which is structured as a society of control on the level of the socius. On the one hand, capitalism consists of a certain number of axioms that enable the denumeration of flows, while, on the other, the society of control forges a connection between the capitalist axiomatic and the infra-individual levels of every (in)dividual. In an ontological and epistemological framework structured like that, art in general and music in particular create zones of non-communication that break affective connections between the infra-individual and the trans-individual in the form of the axiomatic and society of control. With affective non-directionality, music produces a space-time wherein different and new connections between affects may occur. Those affective connections are not exclusively tied to axiomatic denumeration, that is, the production of surplus value, but potentially to the production of surplus life.
\end{abstract}

Keywords: affect, non-directionality, music, immanence, capitalism

Writing about what art is, describing the structure of a work of art is and what it does, Gilles Deleuze and Félix Guattari argued the following: "The composite sensation, made up of percepts and affects, deterritorializes the system of opinion that brought together dominant perceptions and affections within a natural, historical, and social milieu. But the composite sensation is reterritorialized on the plane of composition ... At the same time the plane of composition involves sensation in a higher deterritorialization, making it pass through a sort

* Author contact information: andrija.filipovic@fmk.edu.rs 
of deframing which opens it up and break it open onto an infinite cosmos". ${ }^{1}$ In this quotation, two planes are distinguished: the "natural, historical, and social milieu" and the "infinite cosmos"; their relationship and the role of music therein form the topic of this essay. Namely, Deleuze and Guatari's "natural, historical, and social milieu" is in fact the plane of relative immanence, which is produced by capitalism, while their "infinite cosmos" is that of absolute immanence. As an assemblage, music, as well as art in general, is produced in the conditions of the relative immanence of capitalism, ${ }^{2}$ but in such a way that it always points to the level of absolute immanence. Art does this by creating "zones of non-communication", what I would call affective non-directionality, whereby it generates the possibility of temporarily interrupting affective, and potentially also every other kind of involvement in the axiomatic web of capitalism ("dominant perceptions and affections"), which produces human capital by direct and unmediated relating of the infra-individual and trans-individual relations of individuals (or, better and more precisely, dividuals).

First, one must define the concept of immanence. The concept of immanence is a key concept in Deleuze's (and Guattari's) philosophy, intended to revalue and turn around previous philosophy, which focused on being qua static being, thereby prioritizing the concepts of one, substance, and identity, at the expense of the concepts of difference, multitude, and becoming. Therefore, the

${ }^{1}$ Gilles Deleuze and Félix Guattari, What Is Philosophy?, London/New York, Verso, 2009, 196-197.

${ }^{2}$ Deleuze and Guattari distinguish between two axes of assemblages in general, including artistic assemblages - the horizontal and the vertical. On the horizontal axis, an assemblage consists of content and expression. Its contents comprise the machinic assemblage of bodies, their action and affection, the mixing of bodies that affect one another. Expression comprises collective assemblages of propositions, acts, and attitudes, non-bodily transformations that are ascribed to bodies. On the vertical axis, an assemblage has its territorial sides that stabilize and reterritorialize it, on the one hand, and, on the other hand, its borders of deterritorialization that disperse it. Given the simultaneity of the (re)territorializing and deterritorializing poles on the vertical axis and the mutual determination of contents and expression, one must redefine the positing of the art and culture assemblage in its relations with socio-economic-political domains. I would define that positing as becoming and complicity. Becoming determines the aspect of deterritorialization, the emergence of lines of flight due to the assemblage and the body coming together in a sensory impression that breaks up the sensual-motoric circuits established in habit and memory. Complicity determines the aspect of (re)territorialization, the fact that the process of deterritorialization is always temporary, that lines of flight are momentary, that expression and content correspond and are mutually determined. In other words, there is no absolute rupture or break with immanence, in which the art and culture assemblage emerges and is (trans)individualized. Cf. Gilles Deleuze and Félix Guattari, A Thousand Plateaus, London, Continuum, 2004, 97-98. 
aim was to invent an ontology based on the univocity of being, but so that the univocity of being refers to difference. Deleuze concluded that being could be expressed in only one way - "Being is said in a single and same sense of everything of which it is said, but that of which it is said differs: it is said of difference itself"3 - which produces a conceptual twist whereby being is expressed as becoming, identity as difference, and one as multitude. It was likewise necessary to perform a critique of representation and representational thought, which in fact formed the foundations of the ontology of one/identity/substance. Substance is one of Aristotle's categories, along with quality, quantity, time, place, relation, modality, condition, action, and affection. Before substance, there is being as the cause of all categories. According to Deleuze, one arrives at these categories by way of analogy in judgement. From substance and other categories stems the difference between the corporeal and the incorporeal, which defines the concept of the body, by way of identity in concept. The concept of the body contains, as its specific differences, the predicates of the animate and the inanimate, which, in turn, define the concept of a living thing. Going further, a living thing may be sensient or non-sensient, which defines the concept of the animal. An animal may be rational or irrational, which defines the concept of the human as the sensible animal. Deleuze describes this process as opposition in predicates. By way of similarities in perception, one arrives at individual differences, that is, at individual people. ${ }^{4}$ Analogy in judgement, identity in concept, opposition in predicates, and similarity in perception constitute the fourfold basis of representation and representational thought. ${ }^{5}$

To get to absolute immanence and a radical philosophy of difference, in Difference and Repetition, Deleuze performed a basic (or, rather, debasing) critique of representation, which, by way of analogy, identity, opposition, and similarity, "stifles" difference as difference, multitude, and becoming, thus also effecting a desubstantialization of reality. That in turn means that immanence is that which comes "before" the split between subject and object (therefore, before representational thought), and Deleuze and Guattari referred to this form of immanence as absolute immanence. As such, absolute immanence comprises "virtuality, event, singularity", 6 unlike substances, bodies, and things on the plane of formed

\footnotetext{
${ }^{3}$ Gilles Deleuze, Difference and Repetition, London/New York, Continuum, 2001, 36.

${ }^{4}$ In this presentation, I followed the Porphyrian tree in Daniel W. Smith, "The Doctrine of Univocity: Deleuze's Ontology of Immanence", in: Essays on Deleuze, Edinburgh, Edinburgh University Press, 27-42.

${ }^{5}$ Deleuze, Difference and Repetition, 29.

${ }^{6}$ Gilles Deleuze, "Immanence: A Life", in: Pure Immanence: Essays on a Life, New York, Zone Books, 2001, 25-33.
} 
Filipović, A.: Zones of Non-communication: Music and the Relative Immanence...

materiality, that is, on the plane of relative immanence. The plane of absolute immanence is a purely virtual plane, the plane of non-personal life in general, which is why it is "matter [as] the plane of consistency or Body without organs, in other words, the unformed, unorganized, nonstratified, or destratified body and all its flows: subatomic and submolecular particles, pure intensities, prevital and prephysical free singularities". ${ }^{7}$ Absolute immanence is that "infinite cosmos" from the quotation above, that on which the "Planomenon" emerges, as a conceptual web, to decrease infinite velocities, for the sake of creating "the slow beings' that we are". ${ }^{8}$ In a certain sense, it is chaos, but chaos as an assemblage of infinite speeds: "Chaos makes chaotic and undoes every consistency in the infinite". ${ }^{9}$ And further: "We will say that $T H E$ plane of immanence is, at the same time, that which must be thought and that which cannot be thought. It is the nonthought within thought. It is the base of all planes, immanent to every thinkable plane that does not succeed in thinking it. It is the most intimate within thought and yet the absolute outside - an outside more distant than any external world because it is an inside deeper than any internal world". ${ }^{10}$ In this way, as that chaotic virtual, absolute immanence becomes the necessary ontological condition of all that becomes, including the immanence of the capitalist axiomatic.

As a "natural, historical, and social milieu", relative immanence is in fact the Socius determined by the capitalist machine. The Socius or social machine is always determined by the flows that constitute it and its basic function is the coding of those flows. ${ }^{11}$ The development of coding proceeded from the primitive territorial machine, which coded its flows by way of marital and blood kinship, to the emergence of the state and a specific mode of coding - overcoding. The state emerged in multiple forms, depending on the qualitative change of flows. For instance, the despotic form collapsed, that is, changed at that moment when decoded flows started appearing that escaped the previous mode of coding. ${ }^{12}$ The state changes by overcoding decoded flows, as well as by retain-

\footnotetext{
${ }^{7}$ Deleuze and Guattari, A Thousand Plateaus, 43.

${ }^{8}$ Deleuze and Guattari, What Is Philosophy?, 36.

${ }^{9}$ Ibid., 42 .

${ }^{10}$ Ibid., 59.

11 "Flows of women and children, flows of herds and of seed, sperm flows, flows of shit, menstrual flows: nothing must escape coding"; Gilles Deleuze and Félix Guattari, Anti-Oedipus: Capitalism and Schizophrenia, Minneapolis, University of Minnesota Press, 2003, 142.

12 " [I]t must invent specific codes for flows that are increasingly deterritorialized, which means: putting despotism in the service of the new class relations; integrating the relations of wealth and poverty, of commodity and labor; reconciling market money and money from
} 
ing and partly transforming earlier codes. The despotic form thus retained some features of the primitive territorial machine, while the capitalist social machine retained the role of the state as an overcoding machine. The specificity of the capitalist machine lies in "the generalized decoding of flows, the new massive deterritorialization, the conjunction of deterritorialized flows". ${ }^{13}$ As a general decoding of flows, that is, as a general deterritorialization, ${ }^{14}$ capitalism is that which lies on the border of all social orders. Still, as the very force of deterritorialization, capitalism has no borders of its own, no exterior other than that which it establishes itself, and that is capital. ${ }^{15}$

Deleuze and Guattari identify seven "givens" in their description of the axiomatic of capitalism. In turn, this axiomatic is defined as "operative statements that constitute the semiological form of Capital and that enter as component parts into assemblages of production, circulation, and consumption". ${ }^{16}$ These include addition/subtraction, saturation, models/isomorphy, power, the included middle, minorities, and undecidable propositions. In the preceding paragraph I already discussed the models and isomorphy of the state and social orders in the conditions of the capitalist axiomatic and therefore I will now move on to the remaining six "givens". The axiom of addition/subtraction states that there is "a tendency within capitalism continually to add more axioms". ${ }^{17}$ Deleuze

revenues; everywhere stamping the mark of the Urstaat on the new state of things"; Ibid., 218.

13 Ibid., 224.

14 Over time, the concepts of territorialization, deterritorialization, and reterritorialization changed, to a degree, their meanings in Deleuze and Guattari's philosophy. Or, more precisely, the registers of their application changed, starting from the psychological register, where deterritorialization signified the liberation of the libido from previously established investments, via the social register, where it signified the liberation of, among other things, the work force, to a complete erasure of anthropocentrism in the deterritorializing and reterritorializing movements of sediments in geological terms, protein constitution, symbiotic relations among species, etc. For more on this, see Eugene Holland, "Deterritorializing 'Deterritorialization': From the 'Anti-Oedipus' to 'A Thousand Plateaus'”, Substance, 1991, 20, $3,55-65$.

15 " [C]apitalism is the only social machine that is constructed on the basis of decoded flows, substituting for intrinsic codes an axiomatic of abstract quantities in the form of money. Capitalism therefore liberates the flows of desire, but under the social conditions that define its limit and the possibility of its own dissolution, so that it is constantly opposing with all its exasperated strength the movement that drives it toward this limit. At capitalism's limit the deterritorialized socius gives way to the body without organs, and the decoded flows throw themselves into desiring-production"; Deleuze and Guattari, Anti-Oedipus, 153.

${ }^{16}$ Deleuze and Guattari, A Thousand Plateaus, 461.

${ }^{17}$ Ibid., 462. 
Filipović, A.: Zones of Non-communication: Music and the Relative Immanence...

and Guattari cite the example of the situation after the First World War, when the effects of economic depression on the one hand and those of revolution on the other forced capitalism to multiply and invent new axioms, in order to find a way to deal with the new role of the state, the labour unions, the workers' status, domestic and foreign markets. In particular, adjusting the domestic market to the demands of foreign markets entails the multiplication and emergence of new axioms. ${ }^{18}$ On the other hand, subtracting axioms is characteristic of the state's totalitarian pole and in that sense the totalitarian state is "the minimum State", because it retains only those axioms that concern "the equilibrium of the foreign sector, reserve levels and the inflation rate". ${ }^{19}$ In fact, this axiom also contains the core of the capitalist axiomatic and the essential problem when it comes to trying to invent new ways of resistance, including art. The axiom of saturation states that the axiomatic of capitalism always confronts its own limits and at the same time, confronting those limits, which it establishes itself, pushes them further and further away. For instance, when capitalism faces a contraction of capital, it pushes its limits by inventing new capital, new industries that will yield higher profits. The fourth axiom, that of power, means that the axiomatic possesses more power than do elements that constitute its models. This is the power "of war, a power incarnated in financial, industrial, and military technological complexes that are in continuity with one another". ${ }^{20}$ The axiom of saturation and that of power determine and assume each other, because, as the limits of the axiomatic shift and spread, it goes without saying that new conflicts will break out and that new territories will emerge (both in terms of land and new ways of producing profit) that will require conquering. The axiom of the included middle is the axiom of unequal exchange that is reflected in the problematic flows of energy-matter, population flows, the flows of food, and urban flows. Together with the remaining axioms, this axiom produces not only the Third World on the peripheries of the First and Second World, but also produces a Third World right in the middle of the First World. The more post-industrial activity is positioned at the centre of the First World, the more is the periphery in terms of underdevelopment built into the First World itself.

The next two axioms will also take us to a discussion of the role of art in the conditions of capitalism. They are the axiom of minority and the axiom of undecidable propositions. "Ours is becoming the age of minorities." 21 A minority is defined by relations between numbers, not by numbers themselves. That in turn

\footnotetext{
${ }^{18}$ Ibid.

${ }^{19}$ Ibid.

${ }^{20}$ Ibid., 466.

${ }^{21}$ Ibid., 469.
} 
means that the minority may even be numerically larger than the majority and yet still be the minority. The essential difference lies in the difference that exists between those two sets, the difference between denumerable and undenumerable sets. Minorities constitute undenumerable sets. The axiomatic reigns only over denumerable sets and that is the axiom of denumerability, while minorities constitute sets that are not subject to axiomatization, that is, that resist it. Minorities are the "'masses", multiplicities of escape and flux". ${ }^{22}$ This is the "calculus" of undenumerable, infinite sets, which "may have its own compositions, organizations, even centralizations; nevertheless, it proceeds not via the States or the axiomatic process but via a pure becoming of minorities". ${ }^{23}$ The final axiom is that of undecidable propositions, which states that "[a]t the same time as capitalism is effectuated in the denumerable sets serving as its models, it necessarily constitutes nondenumerable sets that cut across and disrupt those models". ${ }^{24}$ This is the indeterminate and undecidable, which has the potential to break with the axiomatic. That undecidable is precisely the locus of revolutionary decisions: "Every struggle is a function of all of these undecidable propositions and constructs revolutionary connections in opposition to the conjugations of the axiomatic". ${ }^{25}$ That is the road taken by minorities when they find themselves between the possibilities of integration and destruction. Integration does not solve the problem of the minority, because it does not leave the plane of capital, its axiomatic, or the equilibrium of denumerable sets. On the other hand, one should likewise take care not to fall into the trap of the "plateaus of bureaucracy", that is, the trap of the overcoding functions of the state. In fact, these two planes are merely two sides of the same coin, since the state is a model of realizing the capitalist axiomatic. The problem of minorities lies in the simultaneous drawing of lines of flight, from the plane of capital and from the plane of the state alike. The ontological condition of these lines of flight is precisely absolute immanence and one of the ways to create those lines is art.

However, art faces a difficult task, because it finds itself between the Scylla and Charybdis of the state and the axiomatic. Art must simultaneously face the overcoding of the state and the ceaseless axiomatic of capitalism. Overcoding the flows by means of state apparatuses and the axiomatic of capitalism are inseparably linked, because the function of the state in the conditions of the capitalist axiomatic is to reduce the abstract quality of the axiomatic down to quantity, that is, to turn value into commodity. The state, as a model of realizing the

\footnotetext{
22 Ibid., 470.

${ }^{23}$ Ibid., 471.

${ }^{24}$ Ibid., 472.

25 Ibid.
} 
Filipović, A.: Zones of Non-communication: Music and the Relative Immanence...

axiomatic, is the structure that enables the movements of decoding and deterritorialization. But art is also complicit with them. First, art's mode of operation is precisely deterritorialization, which is one of the main features of the capitalist axiomatic. Therefore, art uses the same means as capitalism. On the other hand, art must deal with clichés, stemming from the processes of overcoding as processes that transfer quality into quantity. Deleuze's term for this assemblage of the mutual contingence of overcoded flows and an abstract axiomatic in the age of contemporaneity is the societies of control, while Guattari calls it the postmedia age. ${ }^{26}$ The societies of control replace the disciplinary societies that Michel Foucault discussed in several places and which marked the $19^{\text {th }}$ and much of the $20^{\text {th }}$ century. However, at the end of the $20^{\text {th }}$ century, discipline, as the mode of organizing knowledge and power, was replaced by "control", which rests on the very movements of deterritorialization. Control rests on "modulation, like a self-deforming cast that will continuously change from one moment to the other, or like a sieve whose mesh will transmute from point to point". ${ }^{27}$ Modulation produces "dividuals", as opposed to the individuals of disciplinary societies, while the masses become data that has its value only on the market of capital. Dividuals are modulated ceaselessly and endlessly and there is no longer a break in switching from one place (of work, say) to another, but always a continuum (continued education, for instance). There is no radical break with the axiomatic, but the task of art lies precisely in using existing means (deterritorialization) to try to draw lines of flight, although from the other hand, it is complicit in overcoding and axiomatization (clichéization).

As a product of overcoding and axiomatization, clichéization stems from thought (doxa), while thought emerges through functionalizing the lived.$^{28}$ More accurately, as a function of the lived, thought emerges when a given quality stands out as shared by a certain number of items and when a given affection (not an affect) stands out as common to a larger number of subjects. Thought emerges as a sort of connection between external perception and the subject's internal condition. Since all that is lived is always-already overcoded and, accordingly, always-already caught in the axiomatic of capitalism, the doxa is always that of the average capitalist, which emerges as the majority's will, accord-

${ }^{26}$ For more on Guattari's concept of the postmedia age, see Félix Guattari, "Postmodern Deadlock and Post-Media Transition”, in: Soft Subversions: Text and Interviews, 1977-1985, New York, Semiotext(e), 2007, 291-300. and Félix Guattari, "Entering the Post-Media Era", Ibid., 301-306.

${ }^{27}$ Gilles Deleuze, "Postscriptum on the Societies of Control”, October, 1992, 59, 4.

${ }^{28}$ Cf. Deleuze and Guattari, What Is Philosophy?, 181. Cf. Žil Delez i Feliks Gatari, Sta je filozofija?, op. cit., 182. 
ing to the model of recognition - "recognition of a quality in perception (contemplation), recognition of a group in affection (reflection), and recognition of a rival in the possibility of other groups and other qualities (communication)". ${ }^{29}$ Therefore, art must break with the lived and majority thinking, which is, as such, overcoded, that is, create zones of non-communication by means of affective non-directionality.

Relatively speaking, on one side, there are the axiomatic of capitalism and society of control, which rests on modulation, while on the other, there are undenumerable sets, undecidable propositions, and zones of non-communication; the dividual finds itself between these two poles. What is the role of music therein? "Music seems to have a much stronger deterritorializing force, at once more intense and much more collective", Deleuze and Guattari write in A Thousand Plateaus, concerning the difference between music and painting. ${ }^{30}$ Also, music makes "audible forces that are not audible in themselves", ${ }^{31}$ by creating a special type of time, which Deleuze calls "non-pulsed" time. The essential quality of this type of time is duration and as such, it "puts us first and foremost in the presence of a multiplicity of heterochronous, qualitative, non-coincident, non-comunicating durations". ${ }^{32}$ In fact, the difference between "pulsed" and "non-pulsed" time is the difference between two types of time, which Deleuze introduced already in Difference and Repetition and The Logic of Sense, the difference between Chronos and Aion as time associated with that which is current and time associated with the virtual. Whereas Chronos-time expresses "the action of bodies and the creation of corporeal qualities" and is "inseparable from the bodies which filled it out entirely as causes and matter ... limited and infinite ... inseparable from circularity and its accidents", Aion-time is "the locus of incorporeal events, and of attributes which are distinct from qualities ... populated by effects which haunt it without ever filling it up ... unlimited, the way that future and past are unlimited, and finite like the instant"; it "stretches out in a straight line, limitless in either direction"; it "always already passes and eternally yet to come, Aion is the eternal truth of time: pure empty form of time". ${ }^{33}$ With its own means

${ }^{29}$ Ibid., 145-146. For more on the functionalization of the lived in music, see my article "Human, all too human: Bare Repetition and the Organism in Minimal Music", New Sound: International Magazine for Music, 2014, 44:2, 156-168.

${ }^{30}$ Deleuze and Guattari, A Thousand Plateaus, 302.

${ }^{31}$ Gilles Deleuze, "Making Inaudible Forces Audible”, in: Gilles Deleuze, Two Regimes of Madness: Texts and Interviews, 1975-1995, New York, Semiotext(e), 2006, 160.

32 Ibid., 157.

${ }^{33}$ Gilles Deleuze, Logic of Sense, London, Continuum, 2010, 189. 
Filipović, A.: Zones of Non-communication: Music and the Relative Immanence...

(sonic material), music therefore generates a special kind of time that points to the pure, empty form of time. That pure, empty form of time is future, that is, the third passive synthesis from Difference and Repetition, which unfounds the first two syntheses (habit and memory). Future becomes the unfounding foundation of the wholesale flow of time. ${ }^{34}$

We may note that a sort of conceptual chain is coming together: relative immanence - the axiomatic of capitalism - society of control - modulation pulsed time - Chronos - the current - habit - memory and absolute immanence - undenumerable set - undecidable propositions - zones of non-communication - non-pulsed time - the virtual - Aion - future. This is a quite rough division and may produce the wrong impression that it is a radical dualism, but it is not so and could not be, given the concept of absolute immanence, which I discussed at the beginning of this essay. It is a matter of a complex interrelation between different aspects of reality, whereby they produce and condition each other. Writing about Pierre Boulez's musical practice, Deleuze argues that

[t]he two space-times alternate and overlap, there is exchange between the two functions of temporalization, even if it is only in the sense that a homogenous division in a striated time gives the impression of a smooth time, while a very unequal distribution in a smooth time introduces directions that evoke striated time through densification or the accumulation of proximities. ${ }^{35}$

Chronos and Aion, relative and absolute immanence, being and becoming are in a dynamic unity where Aion, absolute immanence and becoming constitute the field of appearance, whereas phenomena are determined by Chronos, relative immanence, and being. Dynamic unity denotes the relationship between the field of appearance and a phenomenon, where the field of appearance is constituted by the virtual, incorporeal dimension of the material and the phenomenon by the cultural-social. Reciprocity is reflected in the feedback between the conditions of appearance and the reconditioning of conditions by way of the phenomenon. Briefly, the conditions themselves change along with the phenomenon - "Emergence emerges. Changing changes". ${ }^{36}$

That also means that all levels of the existence of a dividual are involved in the exchange between relative and absolute immanence. In other words, that most personal, as formed and shaped, (and the most depersonal in the form of

\footnotetext{
${ }^{34}$ Cf. Deleuze, Difference and Repetition, 73-84.

${ }^{35}$ Gilles Deleuze, "Occupy without Couting: Boulez, Proust and Time”, in: Two Regimes of Madness: Texts and Interviews, 1975-1995, New York, Semiotext(e), 2006, 295.

${ }^{36}$ Brian Massumi, Parables for the Virtual: Movement, Affect, Sensation, Durham, NC, Duke University Press, 2002, 10.
} 
virtual infra-individual levels) is involved in endless communication with the economic and the social. Especially important is the involvement of the infraindividual level in the socio-economic field. Brian Massumi defines the infraindividual aspect of a dividual as "intensive elements, in intra-action. They are immediately linked variations, held in tension, resonating together in immediate proximity". ${ }^{37}$ Those intensive infra-individual elements are expressed at the level of the dividual where they are marked by "fluctuating indicators" - moods, that is, affects and affections. On the other hand, the infra-individual level is also marked by direct and unmediated communication with other infra-individual levels of other dividuals. In other words, trans-individuality is one of its important qualities. On that quality one might also base a sort of affective politics, since affect is relayed directly, without the subject's impact. ${ }^{38}$ Yet, from another angle, since there is no rupture whatsoever between the relative immanence of the capitalist axiomatic and potential radical ventures in terms of resistance, that is, since the economic field produces a direct impact on the infra-individual level (and vice versa), there emerges the problem of disentangling the tangle of intensive elements, affects, affections, and the axiomatic. One possibility is affective non-directionality. By that I mean the association of affects and affections to an artwork in such a way that the infra-individual level is temporarily separated from its trans-individual involvement in the economic field, that is, the axiomatic of capitalism. ${ }^{39}$ Affective non-directionality brings forth not only the binding of affects to a work of art, but also the potentiality that affects, once

${ }^{37}$ Brian Massuni, The Power at the End of Economy, Durham, University of Duke Press, 2014, 20.

38 "A politics of dividualism would affirm complexity, and the oscillatory autonomies of decision that come with it. It would find ways of tending tendencies, in order to navigate the zone of indistinction between choice and nonchoice in such a way as to effect modulations of becoming that produce self-justifying surplus values of life: pulses of life experienced as worth the living by virtue of the event they are, immanent to the event, as a function of its immediate experiential quality ... A politics of dividualism would operate in the unquantifiable currency of intensity, as opposed to satisfaction ... This would be a directly qualitative, relational, and situational politics ... It would seriously experiment with the notion that freedom is impersonal: that it is at its highest power when decisions move through me, rather than being legislated by my all-too-cognitive, self-deceivingly 'rational' I. It would involve care and sensitivity-care for the event of encounter, sensitivity to dividual-transindividual complexity", Ibid., 101-102.

${ }^{39}$ For a mode of affective non-directionality in the shape of exhausting the body as an organism, see Andrija Filipović, "Musica inhumana: Towards the Posthumanistic Ethical and Aesthtetical Paradigm in Music", New Sound: International Magazine for Music, 2013, 42:2, 156-168. 
Filipović, A.: Zones of Non-communication: Music and the Relative Immanence...

disentangled, might be directed toward forms of time other than the now and the past ${ }^{40}$ namely, toward the future indicated by the non-pulsed time of a musical work of art when sonic material is given form.

As an artistic strategy and tactic, affective non-directionality entails that at a suitable moment and in a suitable situation there will be a deterritorializing unchaining of the involvement of the infra-individual level of dividuals from modulations of the capitalist axiomatic and society of control.

This is how it should be done: Lodge yourself on a stratum, experiment with the opportunities it offers, find an advantageous place on it, find potential movements of deterritorialization, possible lines of flights, experience them, produce flow conjunctions here and there, try out continuums of intensities segment by segment, have a small plot of new land at all times. It is though a meticulous relation with the strata that one succeeds in freeing lines of flight, causing conjugated flows to pass and escape and bringing forth continuous intensities for a $\mathrm{BwO}$ [body without organs]. ${ }^{41}$

Deleuze and Guattari demand that art be an art of diagrams, that it experiment with what is provided on a given stratum, that it come to know all of its details and specifities (geographic, historical, economic, etc.), and only then attempt to produce temporary lines of flight. One must first study the social formation and only then turn to what lies "beneath", to a body without organs, consisting of singularities and intensities.

Art as a diagrammatic practice ${ }^{42}$ in the conditions of the axiomatic of capi-

${ }^{40}$ In Boulez (and Marcel Proust), Deleuze finds at least four modes of time: "There is lost time, which is not a negation but a full function of time. For Boulez, the pulverization of sound or its extinguishing is an affair of timbre, the exitinguishing of timbre, in the sense that timbre is like love and repeats its end rather than its origin. Then there is 're-searched time', the formation of blocks of duration, their journey along the diagonal: they are not (harmonic) chords but veritable hand-to-hand fights, often rhythmic ones, sound or vocal embraces where one of the wrestlers subdues the other, and vice versa, like in the music of Vinteuil. That is the striated force of time. And then there is 're-gained' time; identified, but in the instant. It is the 'gesture' of time or the envelope of fixed. Finally, 'utopian time', as Boulez stated in homage to Messiaen: finding oneself again after penetrating the secret of the Numerals, haunting giant bubbles of time, confronting the smooth - discovering, following Proust's analyses, that human beings occupy 'in time a place much more considerable than the all too limited place reserved for them in space'. Or rather that comes to them when they count"; Deleuze, "Occupy without Counting: Boulez, Proust and Time", 298-299.

${ }^{41}$ Deleuze and Guattari, A Thousand Plateaus, 161.

${ }^{42}$ For more on this, see Stephen Zepke, "Anita Fricek: Contemporary Painting as Institutional Critique", in: Stephen Zepke and Simon O'Sullivan (eds.), Deleuze and Contemporary Art, Edinburgh, Edinburgh University Press, 2011, 63-81. and Simon O'Sullivan, 
talism may only and must be uncontemporary, in the sense that it cannot radically break with the deterritorializing processes of the axiomatic. Attempting to perform a radical break leads either toward blocking the flows of intensities, ${ }^{43}$ or toward a complete desubjectivation, which means a zero degree of every activity. It can only "summon [the people] with all his [its] strength. A people can only be created in abominable sufferings, and it cannot be concerned any more with art or philosophy. But books of philosophy and works of art also contain their sum of unimaginable sufferings that forewarn of the advent of a people. Their resistance in common - their resistance to death, to servitude, to the intolerable, to shame, and to the present". ${ }^{44}$ Resisting the existent, which is overcoded and shaped in line with the axioms of capitalism, rests on acting against the past and the present, for a future that will never come. It rests on moving away from the relative immanence produced by the axiomatic to the borders of absolute immanence, to the "infinite cosmos".

"From Stuttering and Stammering to the Diagram: Deleuze, Bacon, and Contemporary Art Practice", Deleuze Studies, 2009, 3:2, 247-258.

${ }^{43}$ In the guise of a hypochondriac body (whose organs are already destroyed and there is nothing happening any longer), paranoid body (whose organs are under constant attack from external forces, which also keep them going), schizoid body (which fights its own organs with its own resources, but at the price of catatonia), drugged body ("experimental schizophrenic"), masochist body (which seeks to close down completely, so as to force its organs to stop functioning; cf. Deleuze and Guattari, A Thousand Plateaus, 166-167.

${ }^{44}$ Deleuze and Guattari, What Is Philosophy?, 110. 